\title{
Students' Perception of Lecturers' Utilization of Information and Communication Technology (ICT) Tools for Instructional Delivery in Science Education Programme
}

\author{
Iniobong Fred Akpan ${ }^{1} \&$ Atim Edet Itighise ${ }^{1}$ \\ ${ }^{1}$ Department of Science Education, Akwa Ibom State University, Ikot Akpaden, Mkpat Enin L. G. A., Akwa \\ Ibom State, Nigeria \\ Correspondence: Iniobong Fred Akpan, Department of Science Education, Akwa Ibom State University, Ikot \\ Akpaden, Mkpat Enin L. G. A., Akwa Ibom State, Nigeria.
}

Received: March 28, 2019

Accepted: July 3, 2019

Online Published: July 10, 2019

doi:10.20849/jed.v3i2.606

URL: https://doi.org/10.20849/jed.v3i2.606

\begin{abstract}
The study was to investigate students' perception of lecturers in utilizing Information and Communication Technology (ICT) tools in instructional delivery in science education programme in Akwa Ibom State University. The researchers adopted descriptive survey design for the study. The population of the study which also formed the sample for the study were one hundred and thirty eight year three students of the Science Education Department, Akwa Ibom State University, Ikot Akpaden, Mkpat Enin L. G. A. Two research questions were formulated to guide the study. A questionnaire titled "Students' Perception of Lecturers Utilization of Information and Communication Technology Tools Questionnaire (SPLUICTTQ) was used for data collection. The researchers personally administered the questionnaire to the students (respondents) and retrieved immediately after completion. The data was analysed using percentages. The results indicated that students' perception of lecturers' use of email and computer in instructional delivery is $36.23 \%$ and $34.78 \%$ higher than all other ICT tools. The result also revealed excellent utilization of internet and email for instructional delivery as shown in the table with $53.52 \%$ and $60.80 \%$ respectively, while audio tapes and computer were averagely used with $44.20 \%$ and $42.28 \%$ respectively as ICT tools in instructional delivery. The result showed that $44.26 \%$ was the perceived percentage of lecturers not using teleconferencing at all. It was concluded that the recommendations of school net (2006) and that of National Policy on Education on the use of ICT tools in instructional delivery be re-emphasized to encourage lecturers in the Department of Science Education on the use of ICT tools for effective instructional delivery process.
\end{abstract}

Keywords: students perception, utilization, ICT tools, instructional delivery, science education programme

\section{Introduction}

New and emerging technologies challenge the traditional process of teaching and learning and the way education is managed. Information and Communication Technology (ICT) is having a major impact across all science curriculum areas including science education. Science education has certainly been affected by the penetrating influence of ICT especially in the quality and quantity of teaching, learning and distance education (Siyanbola, 2015).Ali (2004) defines ICT as the physical structure of network of computer-based system (hardware, software and media) for the purpose of organizing, processing, communicating, accessing, presenting, storing, retrieving and simplifying information when needed. Similarly, Agomuo (2007) see ICT as a broad-based technology (including its methods, management and application) that supports the creation, storage, manipulation and communication of information.

Simply put ICT is the application of computers and others technologies to the acquisition, organization, storage, retrieval and dissemination of information. Itghise and Wordu (2018) affirmed that the integration of ICT in instructional delivery process is already changing the organization and delivery of education in Nigeria. It provides academics with an opportunity to create rich learning environment for the students which enhanced by the wealth of information and resources on the internet as well as the inclusion of arranged web-based learning element. 


\section{Importance of ICT}

ICT is an indispensable part of the contemporary world. The field of education has certainly been affected by the penetrating influence of ICT worldwide. The importance of ICT in science education cannot be overemphasized. ICT provides increased opportunities for the teachers and students to collaborate through good network with colleagues, thereby increasing communication (Olelewe, 2007).

The application of ICT makes institutions more efficient and productive, thereby engendering a variety of tools to enhance and facilitate teacher's pedagogical activities. It helps teachers to take care of student's individual ability by encouraging the use of different methods of teaching and learning material, thus de-emphasizing teacher-centred and theoretical instructional delivery process. Hence, ICT tools have entered the classroom in a great way to become part of teaching and learning process. ICT according to Tinio (2011) has the potential to:

- Accelerate, enrich and deepen skills

- Motivate and engage students in learning

- Help relate schools experiences to work practices

- Help create economic viability for tomorrow's workers,

- Contribute to radical change in schools

- Provide opportunities for connection between the school and the world.

i. Tinio maintains that when used appropriately, ICT can raise the quality of teaching and learning by transforming it into an engaging-active process connected to real life. Olu (2009) asserts that ICT has become the latest addition to mass media that has greatly extended teachers' ability to teach effectively and the students' ability to learn better. This has informed the growing need by all institutions to adopt ICT into classrooms settings in order to explore efficiencies in terms of programme delivery. ICT in Science Education is the computing and communication facilities and feature that variously support teaching, learning and a range of activities in education. Generally, according to Muazu, Abubakar and Nafisa (2013) the benefit of ICT as permeated all aspects of teaching and learning which is summarized as follows:

i It allow students to have more control on their learning. They think analytically and adopt constructionist approach in some issues. This enables them to collaborate with the teacher in instructional delivery; Hence making teaching and learning dynamic and interactive.

ii. Enhances Students motivation to learn, increased self-confidence and self-esteem which make learning effective and efficient.

iii. ICT gives learners immediate access to richer source of learning materials.

iv. ICT enhances learning across subject areas and removes the barriers of time and location in the provision of learning opportunities. Teaching and learning is made possible to students who cannot avail themselves of formal school opportunities as a result of constraints of time and space.

\subsection{Implications of ICT in Science Education}

The emergence of this new global trend has serious implications on the nature and purpose of science education. Tinio (2011) maintains that education cannot remain a mere avenue for the transmission of a prescribed set of information over a fixed period of time, rather it should promote "learning to learn". This implies that science education via ICT will provide possibilities for a life-long education.

Many countries now regard understanding ICT and mastering its basic skills and concepts as part of the core education curriculum (School Net, 2006). It is in line with these realities that the National Policy on Education (FRN, 2013) came up with some changes and innovations which include the introduction of ICT opportunities in education, so as to survive the global composition in information technology. Akudolu (2002) observes that the right aim at integration of ICT in science education is to establish the type of education system that will produce citizens who can contribute effectively to life in the society.

The education for all monitoring report (2013/2014) states that an education system is only as good as teachers (Udofia and Thomas 2016). While the introduction of ICT in education plays a role in shifting responsibility for learning from teacher to students, ICT does not however, remove the need for classroom leadership, nor does it invalidate related traditional teacher's skills and practices that should be incorporated in the art of teaching (Akpan, Udofia and Thomas, 2016). 
However, ICT implementation in science education programme is a difficult, expensive and complex undertaking that requires a host of issues be considered including infrastructure, curricular change, teachers training, technical supports and so on which requires careful planning (Muazu, Abubakar andNafisa, 2013). Nadio (2003) asserts that integrations of ICT into educational system require a systematic approach that is governed by clear policies and implementation processes and plan.

The National Policy on Education (FRN, 2013) have stressed the urgent need to integrate ICT into teacher education in Nigeria in recognition of it role in advancing knowledge and skills necessary for effective functioning in the Morden world. Integration of ICT into science teacher education (Science teachers inclusive) means conducting teaching and learning activities through the use of ICT facilities. This implies that emerging technologies be interwoven into the total fabrics of teachers training to make technology and science education one (Blurto, 1999). In other word, ICT should be an essential tool in teacher training programme and curriculum.

Modern constructivist educational theory emphasizes critical thinking, problem solving, social negotiation and collaboration of knowledge which Blurton (1999) refers to as pedagogical methods that changed the role of the teacher from a disseminator of information to a learning facilitator (helping students as they are actively engaged with information and materials to construct their own understanding). ICT has the potential for aiding these new educational methods, which enable students by going through its dynamic, interactive, flexible and engaging content.

\section{Statement of the Problem}

It is a known fact that the level of development and utilizing of modern technologies in different countries is determined not only by their material resources but to a large extent by the degree of society's ability to produce, absorb and apply new knowledge. These processes are largely driven by information and communication technologies where scientific knowledge and information increasingly determine new patterns more effectively (Alfred-Jaja \& Ogeibiri, 2016). Modern professional training in science education requires heavily the introduction of ICT. The alternative to the above is to lag behind this development and consequently fail to meet the challenges of the new world order. Nwanewezi (2010) maintains that the availability and utilization of ICT in the teaching and learning has generated serious concern. Despite numerous uses of ICT in the teaching and learning process, several tertiary institutions especially teacher training institutions could be lagging in the use of this technology. This might be because a large number of lecturers still have to fully appreciate the importance of ICT in realizing their teaching objectives, while many may find themselves incompetent to handle ICT as instructional delivery tools. The problem of this study is therefore to determine the students' perception of lecturers' utilization of ICT tools in their instructional delivery in science education programme in Akwa Ibom State University.

\section{Purpose of the Study}

The main purpose of this study was to determine the students' perception of lecturers' utilization of ICT tools for instructional delivery in Science Education programme. Specifically, the study sought to:

1. Determine the perception of science education students on their lecturers' utilization of ICT tools for effective instructional delivery in Akwa Ibom State University, Ikot Akpaden, Mkpat Enin L.G.A

2. Examine the extent lecturers of science education utilize ICT tools for instructional delivery as perceived by students in Akwa Ibom State University, Ikot Akpaden, Mkpat Enin L.G.A, Nigeria.

\section{Research Questions}

The following research questions were formulated to guide the study.

1. What is the perception of science education students on their lecturers' Utilization of ICT tools for effective instructional delivery in Akwa Ibom State University, Ikot Akpaden, Mkpat Enin L.G.A?

2. To what extent does science education Lecturers utilize ICT tools for effective instructional delivery as perceived by students in Akwa Ibom State University, Ikot Akpaden, Mkpat Enin L.G.A?

\section{Methodology}

The researchers adopted the descriptive survey design for the study. The population of the study which also form the sample for the study were one hundred and thirty eight year three science education students of Akwa Ibom State University, Ikot Akpaden, Mkpat Enin L.G.A. The instrument for data collection was a twenty-item structured questionnaire. Students' Perception of Lecturers Utilization of Information and Communication Technology Tools Questionnaire (SPLUICTTQ). The questionnaire contain 10 questions for each research questions. A 4-piont Likert- type rating scale described as Strongly Agree (SD), 4, Agree (A), 3, Disagree (D), 2, 
and Strongly Disagree (SD), 1 point was used to elicit the rating responses from respondents. The questionnaire for research questions one was to elicit information from students on their lecturers' use of ICT tools in their daily lesson delivery that enhanced effective science education instruction. The students were to strongly agreed, agreed, disagreed or strongly disagreed on their lecturers' use of the listed ICT tools. The questionnaire for research question two was to elicit information on the extent of usage of the listed ICT tools. The extent of utilization were rated as Excellent, 4, Average, 3, Below Average, 2 and Not at all, 1 point. The questionnaire was validated by two experts, both of Measurement and Evaluation from Science Education Department of Akwa Ibom State University, Ikot Akpaden, Mkpat Enin L.G.A. Their observations and recommendations were used to produce the final copy of the questionnaire. The reliability coefficient of 0.87 was obtained using Cronbach Alpha analysis. The researchers administered the questionnaire personally with the help of two research assistants after passing through basic orientation. The data collected was analysed using percentages.

\section{Results}

The data was analysed and presented according to the research questions using percentages.

\section{Research Question 1}

What is the perception of science education students on their lecturers' utilization of ICT tools for effective instructional delivery in Akwalbom State University, IkotAkpaden.

Table 1. Percentage of students' perception of lecturers' utilization of ICT tools for instructional delivery. $(\mathrm{N}=$ 138)

\begin{tabular}{|c|c|c|c|c|c|c|}
\hline $\mathbf{S} / \mathbf{N}$ & Items & $\begin{array}{c}\text { Strongly } \\
\text { Agreed } \\
\text { SA }\end{array}$ & $\begin{array}{c}\text { Agreed } \\
\mathbf{A}\end{array}$ & $\begin{array}{c}\text { Disagreed } \\
\text { D }\end{array}$ & $\begin{array}{c}\text { Strongly } \\
\text { DisagreedSD }\end{array}$ & Total \\
\hline 1 & $\begin{array}{l}\text { Linking students to Internet } \\
\text { for effective instruction } \\
\text { delivery }\end{array}$ & $\begin{array}{c}34 \\
24.63 \%\end{array}$ & $\begin{array}{c}31 \\
22.46 \%\end{array}$ & $\begin{array}{c}26 \\
18.84 \%\end{array}$ & $\begin{array}{c}47 \\
34.66 \%\end{array}$ & 100 \\
\hline 2 & $\begin{array}{l}\text { Presenting the lesson using } \\
\text { Multi-media Projector }\end{array}$ & $\begin{array}{c}15 \\
10.86 \%\end{array}$ & $\begin{array}{c}32 \\
23.18 \%\end{array}$ & $\begin{array}{c}33 \\
23.91 \%\end{array}$ & $\begin{array}{c}58 \\
42.02 \%\end{array}$ & 100 \\
\hline 3 & $\begin{array}{l}\text { Use email to share lesson } \\
\text { contents with the students }\end{array}$ & $\begin{array}{c}50 \\
36.23 \%\end{array}$ & $\begin{array}{c}42 \\
30.43 \%\end{array}$ & $\begin{array}{c}28 \\
20.28 \%\end{array}$ & $\begin{array}{c}18 \\
13.04 \%\end{array}$ & 100 \\
\hline 4 & $\begin{array}{l}\text { Use Interactive Whiteboard in } \\
\text { teaching }\end{array}$ & $\begin{array}{c}16 \\
11.59 \%\end{array}$ & $\begin{array}{c}28 \\
20.28 \%\end{array}$ & $\begin{array}{c}37 \\
26.81 \%\end{array}$ & $\begin{array}{c}57 \\
41.30 \%\end{array}$ & 100 \\
\hline 5 & $\begin{array}{l}\text { Use Teleconferencing to } \\
\text { connect other virtual students }\end{array}$ & & & $\begin{array}{c}36 \\
26.08 \%\end{array}$ & $\begin{array}{c}102 \\
73.91 \%\end{array}$ & 100 \\
\hline 6 & Use Audio Tapes in teaching & & $\begin{array}{c}14 \\
10.14 \%\end{array}$ & $\begin{array}{c}37 \\
26.81 \%\end{array}$ & $\begin{array}{c}87 \\
63.04 \%\end{array}$ & 100 \\
\hline 7 & $\begin{array}{l}\text { Delivering Lessons Contents } \\
\text { using Computers }\end{array}$ & $\begin{array}{c}48 \\
34.78 \%\end{array}$ & $\begin{array}{c}41 \\
29.71 \%\end{array}$ & $\begin{array}{c}28 \\
20.25 \%\end{array}$ & $\begin{array}{c}15 \\
15.21 \%\end{array}$ & 100 \\
\hline 8 & $\begin{array}{l}\text { Make use of Photocopiers } \\
\text { Machine when teaching }\end{array}$ & $\begin{array}{c}15 \\
10.56 \%\end{array}$ & $\begin{array}{c}22 \\
15.94 \%\end{array}$ & $\begin{array}{c}45 \\
32.60 \%\end{array}$ & $\begin{array}{c}53 \\
38.40 \%\end{array}$ & 100 \\
\hline 9 & $\begin{array}{l}\text { Use Fax Machine in sharing } \\
\text { lesson content }\end{array}$ & & $\begin{array}{c}18 \\
13.04 \%\end{array}$ & $\begin{array}{c}43 \\
31.15 \%\end{array}$ & $\begin{array}{c}77 \\
55.79 \%\end{array}$ & 100 \\
\hline 10 & $\begin{array}{l}\text { Using Dictating Machines for } \\
\text { lesson purposes }\end{array}$ & & $\begin{array}{c}16 \\
11.59 \%\end{array}$ & $\begin{array}{c}41 \\
28.98 \%\end{array}$ & $\begin{array}{c}83 \\
59.42 \%\end{array}$ & 100 \\
\hline
\end{tabular}


In Table 1, the result showed that students' perception of lecturer's use of email and computer in instructional delivery was $66.66 \%$ and $64.49 \%$ respectively as indicated by strongly agreed and agreed options compared to other ICT tools. The result also showed that the use of Teleconferencing, Audiotapes, fax machines and dictating machine were perceived very low as greater number of respondents ticked disagreed and strongly disagreed and the percentage were $100 \%, 89.85 \%, 86.94 \%$ and $88.40 \%$ respectively. This implies that the students do not have any perceived evidence on their lecturers' use of ICT tools in instructional delivery process.

\section{Research Question 2}

To what extent do science education lecturers utilize ICT tools for effective instructional delivery in Akwa Ibom

State University, Ikot Akpaden.

Table 2. Percentage of lecturer's extent of ICT tools utilization for instructional delivery $(\mathrm{N}=138)$

\begin{tabular}{|c|c|c|c|c|c|c|}
\hline $\mathbf{S} / \mathbf{N}$ & ICT TOOLS & $\begin{array}{c}\text { Excellent } \\
\text { use }\end{array}$ & Average Use & $\begin{array}{c}\text { Below Average } \\
\text { Use }\end{array}$ & Not at all & Total \\
\hline \multirow{2}{*}{1} & \multirow{2}{*}{ Internet } & 78 & 34 & 22 & 40 & \multirow{2}{*}{100} \\
\hline & & $56.53 \%$ & $24.63 \%$ & $15.94 \%$ & $2.89 \%$ & \\
\hline \multirow{2}{*}{2} & \multirow{2}{*}{ Multi-media Projector } & 25 & 29 & 43 & 41 & \multirow{2}{*}{100} \\
\hline & & $18.12 \%$ & $21.01 \%$ & $31.15 \%$ & $29.71 \%$ & \\
\hline \multirow{2}{*}{3} & \multirow{2}{*}{ Email } & 84 & 40 & 10 & 4 & \multirow{2}{*}{100} \\
\hline & & $60.86 \%$ & $28.98 \%$ & $7.25 \%$ & $2.89 \%$ & \\
\hline \multirow{2}{*}{4} & \multirow{2}{*}{ Interactive Tools } & 28 & 34 & 30 & 48 & \multirow{2}{*}{100} \\
\hline & & $18.34 \%$ & $24.63 \%$ & $21.74 \%$ & $34.7 \%$ & \\
\hline \multirow{2}{*}{5} & \multirow{2}{*}{ Teleconferencing } & & & 77 & 61 & \multirow{2}{*}{100} \\
\hline & & & & $55.79 \%$ & $44.20 \%$ & \\
\hline \multirow{2}{*}{6} & \multirow{2}{*}{ Audio Tapes } & 50 & 61 & 22 & 5 & \multirow{2}{*}{100} \\
\hline & & $36.23 \%$ & $44.20 \%$ & $15.94 \%$ & $3.62 \%$ & \\
\hline \multirow{2}{*}{7} & \multirow{2}{*}{ Computers } & 24 & 58 & 28 & 28 & \multirow{2}{*}{100} \\
\hline & & $17.39 \%$ & $42.02 \%$ & $20.28 \%$ & $20.28 \%$ & \\
\hline \multirow{2}{*}{8} & \multirow{2}{*}{ Photocopiers } & 21 & 33 & 31 & 53 & \multirow{2}{*}{100} \\
\hline & & $15.21 \%$ & $23.91 \%$ & $22.46 \%$ & $38.40 \%$ & \\
\hline \multirow{2}{*}{9} & \multirow{2}{*}{ Fax Machine } & 20 & 28 & 32 & 48 & \multirow{2}{*}{100} \\
\hline & & $14.49 \%$ & $20.28 \%$ & $23.18 \%$ & $34.78 \%$ & \\
\hline \multirow{2}{*}{10} & \multirow{2}{*}{ Dictating Machines } & 18 & 15 & 34 & 71 & \multirow{2}{*}{100} \\
\hline & & $13.04 \%$ & $10.86 \%$ & $24.63 \%$ & $51.45 \%$ & \\
\hline
\end{tabular}

Table 2 showed the responses by the respondents on the extent of Science Education Lecturers utilization of ICT tools for effective instructional delivery in Akwa Ibom State University. The results revealed that science education lecturers excellently utilize internet and email tools for instructional delivery as shown in the table as $56.52 \%$ and $60.86 \%$ respectively. From the above data, lecturers averagely used Audiotapes, $44.20 \%$ and computer $42.02 \%$ while $44.20 \%$ do not use teleconferencing at all for instructional delivery process.

\section{Discussion of Findings}

The results on Table 1 show that there is a significantly low utilization of ICT tools in instructional delivery by science education lecturers in Akwa Ibom State University as perceived by the students. This result call for the need to bring into science education the use of ICT tools which is the bend of the 21 st century education yearning globally. The importance of Information Technology cannot be overemphasized as information 
technology is having a penetrative influence on the quality and quantity of teaching, learning and distance education as observed by Siyanbola (2015).

This result is in agreement with the finding of Alfred-Jaja \& Ogeibiri (2016) who in their study of students' perception of lecturers in utilizing Information and Communication Technology for instructional delivery in Business Education programme found that most of the essential ICT tools were still not utilized in most of our institutions of higher learning in instructional delivery even where these tools are available. Therefore, the need to give concerting efforts in incorporating ICT tools in science education delivery should be a priority to the university authorities in line with the best global practices.

The result on Table 2 revealed a significant low extent of science education lecturers' utilization of ICT tools for instructional delivery in Akwa Ibom State University, Ikot Akpaden, Mkpat Enin L. G. A., Nigeria. The result suggests that the recommendation of School Net (2006) and FRN (2013) that the need for changes and innovations with particular emphasis on introduction of ICT opportunities in education should be re-emphasized as most of the ICT tools were not utilized in instructional delivery in the institution.

The finding is in agreement with Adebayo (2015) who in a study of awareness and utilization of ICT tools by mathematics lecturers and students found that $80 \%$ of the lecturers were aware of the ICT tools but do not use them due to inadequate skills on how to use the tools. The study is also in agreement with a related study by Onasanya, Shelm andAdefuye (2011) who found a low level of literacy and utilization of ICT tools among 240 Science and Health Education teachers drawn from State Secondary Schools in Oyo. However, the implementation of ICT in science education is faced with some implementation problems as observed by (Muazu, Abubakar and Nafisa, 2013). The need to overcome these problems which include among others infrastructure, curricula change, teachers training, technical supports cannot be overemphasized as the integration of ICT tools in science education will go a long way to improve the teaching and learning of science at all levels of education in the state and the country at large.

\section{Conclusion}

The use of ICT tools provide opportunities for remarkable change and transformation in teachers' education due to their ability to draw learning closer to the learners and make teaching easier and simpler to the lecturers. All science educators should therefore be exposed to the knowledge of a variety of ICT tools available for instructions and the skills of using them for teaching. Teacher education is the best level to strengthen the use of ICT tools in education since teachers remain the most important factor in any education reform. It may appear too expensive, but it is a small price to pay for a potentially monumental socio-economic benefit of the students and the society as put across.

\section{Recommendations}

Based on the findings of the study, the following recommendations were made for effective teaching and learning of science education using ICT tools in Science Education Department of Akwa Ibom State University.

1. To create ICT enabling teaching and learning environment, it is necessary to provide ICT training for Lecturers. In essence, teacher educators' policies and practices should be shaped in order to ameliorate teachers' lack of skills in the use of ICT tools.

2. Monitoring of the state of ICT facilities in the Science Education Department in Akwa Ibom State University should be carried out to determine those facilities that need to be replaced or upgraded for effective instruction delivery.

3. Government should regulate telecommunication rates in order to ensure affordable ICT access for all Lecturers just like the US Telecommunication Act of 1996 (Blurton, 1999) which sought to help schools and Libraries obtain access to telecommunication services and technologies at discount rates.

4. Problems deterring ICT usage should be addressed such as poor net work to encourage the frequent use of ICT in the teaching and learning process.

\section{References}

Adebayo, O. (2015). The awareness and use of ICT tools in teaching and learning mathematics at Colleges of Education in Nigeria. EDULEARN Proceedings, 3184-3189.

Agomuo, E.E. (2009). Business education on the 'e'era: Implications for national education reforms. Business Education Book of Reading, I(8), 241-254. 
Akpan, I.F., Udofia, S.E., \& Thomas, N. (2016). Innovative use of ICT in science teacher education for sustainable national development. Journal of Nigeria Association for Educational Media and Technology, $20(1), 37-44$.

Akudolu, L. (2002). Information and Communication Technology (ICT) Carfred education: A necessity for national development. Nigeria Journal of Computer Literacy, 3(1), 10-18.

Alfred - Jaja, S.W., \&Ogeibiri, C. (2016). Students' perception of lecturers in utilizing Information and Communication Technology (ICT) for instructional delivery in Business Education Programme. Journal of Educational Realities, 1(1), 80-87.

Ali, A. (2004). Information and communication technology and enhancement of education in the 21 st century. In C.V. Nneka \& A.A. Okafor (Eds.), Information in the 21st century in Nigeria. Imunce: Federal College of Education (Technical). 1-6

Blurto, C. (1999). New derivations of ICT-use in education. Retrieved 29 September 2011, from $\mathrm{http} / /$ www.unesco.org/education/education.pr/iwt/ndf

Federal Republic of Nigeria. (2013). National Policy on Education. Lagos: NERDC Press.

Itighise, A.G., \& Wordu, N.C. (2016). Concept and uses of information and communication technology (ICT) in Education. In R.R. Okoye, C.U. Eze, \& M.U. Oluwole (Eds.), Information and Communication Technology and Education in Nigeria: challenges and prospects. Ibadan: Global academic Group Online Academic Resources.

Muazu, M.H., Abubakar, Z.S., \&Nafisa, T. (2013). Challenges of integrating information and communication technology: Psychological perspective. Journal of Education and Leadership Development, 5(2),74-80.

Naido, V. (2003). ICT in education policy-reflecting on key issues. A paper presented at ICTs in African Schools; A pan-African workshop focusing ICT support for education system in Africa, Held in Botswana.

Nwanewezie, C.M. (2010). Problems in business education research in ICT-era as perceived by lecturers of business education. Business Education Journals, 2(6).

Olelewa, C.J. (2007). Functional ICT literacy and educational enhancement in Nigeria. Journal of Applied Literacy and Reading Enugu, Pan Africa Publishers.

Olu, A.J. (2009). The role of Information and Communication Technology (ICT) in the teaching of science education. A paper presented at the annual school of science seminar, FCE, Yola.

Onasanya, S.A., Shelm, O.O., \& Adefuye, A.L. (2011).Teachers' awareness and extent of utilization of Information and Communication Technology for effective Science and Health education in Nigeria. Singapore Journal of Scientific Research, 1, 49-58. https://doi.org/10.3923/sjsres.2011.49.58

School Net Nigeria. (2006). Basic ICT skills training programme for teachers in colleges of education. Proceedings of the workshop for lecturers of FCE, Yola, from $4^{\text {th }}-8^{\text {th }}$ December.

Siyanbola, W.O. (2015). Information technology policy and higher education in Nigeria. National Centre for technology management, Obafemi Awolowo University, Ile-Ife.

Tinio, V.L. (2011). ICT in education. Retrieved 29 September 2011, from www.suigontre.com

\section{Copyrights}

Copyright for this article is retained by the author(s), with first publication rights granted to the journal.

This is an open-access article distributed under the terms and conditions of the Creative Commons Attribution license (http://creativecommons.org/licenses/by/4.0/). 